\title{
Introduction to the RoSE special issue on the impact of economic growth and fossil fuel availability on climate protection
}

\author{
Elmar Kriegler ${ }^{1} \cdot$ Ioanna Mouratiadou $^{1}$. \\ Gunnar Luderer ${ }^{1}$ • Jae Edmonds ${ }^{2}$. \\ Ottmar Edenhofer ${ }^{1,3,4}$
}

Received: 18 March 2016 / Accepted: 25 March 2016

(C) Springer Science+Business Media Dordrecht 2016

A large body of research has shown that limiting global mean temperature increase to $2{ }^{\circ} \mathrm{C}$ above preindustrial levels requires a global phase-out of greenhouse gas emissions by the end of the century (see Clarke et al. 2014a, for an overview). This literature has explored several dimensions of climate stabilization pathways with integrated assessment models (IAMs, Weyant et al. 1996), notably their sensitivity to greenhouse gas (GHG) concentration targets (see e.g. Clarke et al. 2009; Edenhofer et al. 2010; Kriegler et al. 2014, for model comparison studies) and techno-economic assumptions (e.g. Clarke et al. 2008; McJeon et al. 2011; Bosetti et al. 2015), the role of mitigation technologies, energy end-use sectors, and energy demand (see Edenhofer et al. 2010; Luderer et al. 2012; Tavoni et al. 2012; Riahi et al. 2012; Kriegler et al. 2014; Krey et al., 2014, for model comparison studies), the role of fragmented or moderate near term mitigation action (see Clarke et al. 2009; Van Vuuren and Riahi 2011; Jakob et al. 2012; Kriegler et al. 2013b; Tavoni et al. 2015; Riahi et al. 2015; Kriegler et al. 2015; Luderer et al. 2013a, for model comparison studies), combined effects of delayed mitigation and technology availability (see Riahi et al. 2015, for a model comparison study and Luderer et al. 2013b; Rogelj et al. 2013a, 2013b, for individual model sensitivity

This article is part of a Special Issue on "The Impact of Economic Growth and Fossil Fuel Availability on Climate Protection" with Guest Editors Elmar Kriegler, Ioanna Mouratiadou, Gunnar Luderer, Jae Edmonds and Ottmar Edenhofer.

Elmar Kriegler

kriegler@pik-potsdam.de

1 Potsdam Institute for Climate Impact Research, Potsdam, Germany

2 Pacific Northwest National Laboratory, Joint Global Change Research Institute at the University of Maryland, College Park, MD, USA

3 Technische Universität Berlin, Berlin, Germany

4 Mercator Research Institute on Global Commons and Climate Change, Berlin, Germany 
analyses), and regional mitigation pathways (see Calvin et al. 2012; Knopf et al. 2013; Capros et al. 2014; Clarke et al. 2014b; Calvin et al. 2016, for model comparison studies on Asia, Europe, USA, and Latin America, respectively). However, the sensitivity of mitigation pathways to assumptions about underlying socio-economic developments is much less explored (but see Morita et al. 2000; Webster et al. 2012; Gillingham et al. 2015; Riahi et al. 2016). This is the focus of the RoSE study ("Roadmaps toward Sustainable Energy futures"; www.rose-project.org) presented in this special issue of Climatic Change.

Many of the underlying drivers of emissions and emissions reductions such as population and economic growth, fossil fuel availability, and progress in low carbon energy technologies are inherently uncertain, and often accounted for through the use of scenarios (Nakicenovic et al. 2000; Riahi et al. 2016). It is therefore an important question how uncertainty about longterm socio-economic and technological developments affects the integrated assessment of climate change mitigation pathways. The RoSE study allows addressing this question with regard to economic growth and fossil resource assumptions, as it is the first to control for these assumptions in a multi-model study of baseline and mitigation pathways. More concretely, RoSE conducted a model comparison on harmonized variations in economic growth, population and fossil resource assumptions across four integrated assessment models: GCAM (Edmonds and Reilly 1985; Edmonds et al. 1997; http:/wiki.umd.edu/gcam), IPAC (Jiang et al. 2000), REMIND (Luderer et al. 2015; Bauer et al. 2012; Leimbach et al. 2010; http://pikpotsdam.de/research/sustainable-solutions/models/remind), and WITCH (Bosetti et al. 2006; Bosetti et al. 2009; http://doc.witchmodel.org/). This fills an important gap in the literature, since previous sensitivity studies mostly focused on technology assumptions (Clarke et al. 2008; McJeon et al. 2011; Bosetti et al. 2015).

The results of the RoSE study are presented in this special issue and the underlying RoSE scenarios are published in a database accessible at www.rose-project.org/database. In addition, key findings were synthesized in a report for policy makers, stakeholders and the public (Kriegler et al. 2013a). The special issue begins with an overview article (Kriegler et al. 2013c) identifying robust and sensitive features of mitigation pathways as projected by the four IAMs in the RoSE study. The article shows that economic growth and fossil resource assumptions substantially affect baseline developments, but that their influence on climate mitigation pathways is smaller due to overriding requirements imposed by the long-term climate policy target. Since many quantities characterizing mitigation pathways are measured against a baseline without climate policy (e.g. mitigation costs and emissions reductions), baseline uncertainty remains highly relevant for the assessment of mitigation pathways. However, Kriegler et al. find that while baseline assumptions can have substantial effects on mitigation costs and carbon price estimates, those estimates are more strongly affected by the choice of climate target and model differences.

While the overview article focused on the synthesis of global results from the multi-model ensemble, a series of papers in the special issue provide a deeper look into the sectoral and regional aspects of the RoSE scenarios. Several papers use the strength of individual models to look into the effect of socio-economic assumptions and climate policy targets onto selected sectors. Bauer et al. (2013) focus on the response of global fossil fuel markets to climate policy, economic growth and fossil fuel availability using the REMIND model. They provide a detailed analysis of fossil fuel use and fossil fuel price developments, and show that global and regional fossil fuel rents depreciate significantly under climate policy, but these losses are overcompensated by a newly emerging carbon rent due to climate policy. De Cian et al. (2013) investigate the impact of economic growth and fossil resource assumptions on investments and 
induced technological change in the energy sector using the WITCH model. They focus on baseline scenarios to show that high economic growth and fossil fuel scarcity can have positive impacts on low carbon innovation, but they alone are not sufficient to achieve climate policy targets. Calvin et al. (2013b) use the endogenous representation of land use dynamics in the GCAM model to explore the implications of fossil fuel availability on bioenergy use and land use emissions. They show that limited oil availability has a major impact on both coal-toliquids and biofuel deployments, with significant impact on land use emissions. Cherp et al. (2013) evaluate the energy security implications of mitigation policies using results from the REMIND and WITCH models. They find that mitigation policies significantly reduce the risks and increase the resilience of energy systems in the first half of the century, and also make energy supply and energy trade less dependent upon assumptions of fossil fuel availability and GDP growth, and thus more predictable than in the baseline scenarios. Schäfer et al. (2014) use the U.S. transportation sector projections in the RoSE scenarios of the GCAM and REMIND models to derive these models' intrinsic elasticities of transportation energy use and compare them with historical trends and literature estimates. Their econometric analysis finds the elasticity estimates roughly comparable with the largest difference occurring for the models' comparatively low income elasticity of transportation energy use.

The RoSE study also looked into the regional details of baseline and mitigation pathways. Mouratiadou et al. (2015) provide a comparative analysis of regional emissions pathways (Africa, India, China, Europe, and the U.S.) with the REMIND model. They show that emission trajectories of developed, emerging and developing regions differ significantly due to differences in economic growth rates, energy and carbon intensity developments, and mitigation potentials. This is further amplified by variations in energy and carbon intensity due to uncertainty in economic growth and fossil fuel availability, but the core findings on regional mitigation strategies are largely unaffected by this uncertainty. Chen et al. (2013) take an in-depth look into energy transition pathways for China, by comparing results from a national energy system model, China-TIMES (Chen 2005; Chen et al. 2007), with the projections of the global integrated assessment models for China. This innovative approach allows to better understand differences in decarbonization strategies between national and global modelling approaches, and their underlying causes like differences in assumptions about technology availability and performance, national policies, and energy demand response to climate policy. Calvin et al. (2013a) conduct one of the first comparative analyses of energy transformation scenarios for Africa, whose future energy demand and GHG emissions are largely uncertain. They show that population and economic growth rates will strongly influence Africa's future energy use and emissions, which could account for between $5 \%$ and $20 \%$ of global emissions in 2100 . Although electric capacity and electricity use per capita rise with income, even by mid-century they do not reach levels observed in developed countries today.

Finally, the RoSE project explored the impact of delaying stringent mitigation action until 2020 and 2030 on the transitional challenges to keep the $2{ }^{\circ} \mathrm{C}$ target within reach. Based on a multi-model analysis of delayed action scenarios, Luderer et al. (2013a) show that following weak near-term action to 2030 will result in significantly more aggressive energy transformation requirements after 2030, and thus much stronger transitional economic impacts, than would be entailed by weak action only until 2020. This result casts doubt on the political feasibility of keeping the $2{ }^{\circ} \mathrm{C}$ target within reach without a significant strengthening of mitigation efforts before 2030 - a highly relevant finding for the review of the intended nationally determined contributions (INDCs) currently proposed under the Paris Agreement 
(UNFCCC 2015). Taken together, the RoSE special issue provides a major contribution to our understanding of global mitigation pathways, their robust and sensitive features under uncertainty about key socio-economic developments, and a number of sectoral and regional aspects of these pathways.

Acknowledgments The RoSE project and the work presented in the RoSE special issue were supported by Stiftung Mercator.

\section{References}

Bauer N, Baumstark L, Leimbach M (2012) The REMIND-R model: the role of renewables in the low-carbon transformation-first-best vs. second-best worlds. Clim ChangE 114:145-168

Bauer N, Mouratiadou I, Luderer G, et al. (2013) Global fossil energy markets and climate change mitigation an analysis with REMIND. Clim Change. doi:10.1007/s10584-013-0901-6. (this issue)

Bosetti V, Carraro C, Galeotti M, Massetti E, Tavoni M (2006) WITCH: a world induced technical change hybrid model. Energy J, 27 (Special Issue) 2:13-38.

Bosetti V, Carraro C, De Cian E, Sgobbi A, Tavoni M (2009) The 2008 WITCH Model: New Model Features and Baseline. FEEM Working Paper 2009.085

Bosetti V, Marangoni G, Borgonovo E, et al. (2015) Sensitivity to energy technology costs: A multi-model comparison analysis. Energy Policy 80:244-263. doi:10.1016/j.enpol.2014.12.012

Calvin K, Clarke L, Krey V, et al. (2012) The role of Asia in mitigating climate change: Results from the Asia modeling exercise. Energy Econ 34(Supplement 3):S251-S260. doi:10.1016/j.eneco.2012.09.003.

Calvin K, Pachauri S, Cian E, Mouratiadou I (2013a) The effect of African growth on future global energy, emissions, and regional development. Clim Change. doi:10.1007/s10584-013-0964-4. (this issue)

Calvin K, Wise M, Luckow P, et al. (2013b) Implications of uncertain future fossil energy resources on bioenergy use and terrestrial carbon emissions. Clim Change. doi:10.1007/s10584-013-0923-0. (this issue)

Calvin KV, Beach R, Gurgel A, et al. (2016) Agriculture, forestry, and other land-use emissions in Latin America. Energy Econ. doi:10.1016/j.eneco.2015.03.020. (in press)

Capros P, Paroussos L, Fragkos P, et al. (2014) European decarbonisation pathways under alternative technological and policy choices: A multi-model analysis. Energy Strateg Rev 2:231-245. doi:10.1016/j.esr.2013. 12.007

Chen W (2005) The costs of mitigating carbon emissions in China: findings from China MARKAL-MACRO modeling. Energ Policy 33(7):885-896

Chen W, Wu Z, et al. (2007) Carbon emission control strategies for China: A comparative study with partial and general equilibrium versions of the China MARKAL model. Energy 32(1):59-72

Chen W, Yin X, Zhang H (2013) Towards low carbon development in China: a comparison of national and global models. Clim Change. doi:10.1007/s10584-013-0937-7. (this issue)

Cherp A, Jewell J, Vinichenko V, et al. (2013) Global energy security under different climate policies, GDP growth rates and fossil resource availabilities. Clim Change. doi:10.1007/s10584-013-0950-x. (this issue)

Clarke L, Kyle P, Wise M, et al. (2008) CO2 emissions mitigation and technological advance: an updated analysis of advanced technology scenarios. PNNL Report. Pacific Northwest National Laboratory, Richland, WA

Clarke L, Edmonds J, Krey V, et al. (2009) International climate policy architectures: Overview of the EMF 22 International Scenarios. Energy Econ. 31(Supplement 2):S64-S81. doi:10.1016/j.eneco.2009.10.013.

Clarke L, Jiang K, Akimoto K, et al. (2014a) Assessing Transformation Pathways. In: Edenhofer O, Pichs-Madruga R, Sokona Y, et al. (eds) Climate Change 2014: Mitigation of Climate Change. Contribution of Working Group III to the Fifth Assessment Report of the Intergovernmental Panel on Climate Change. Cambridge University Press, Cambridge, United Kingdom and New York, NY, USA

Clarke L, Fawcett A, Weyant JP, et al. (2014b) Technology and U.S. Emissions Reductions Goals: Results of the EMF 24 Modeling Exercise. Energy J 35:9-32. doi:10.5547/01956574.35.SI1.2

De Cian E, Sferra F, Tavoni M (2013) The influence of economic growth, population, and fossil fuel scarcity on energy investments. Clim Change. doi:10.1007/s10584-013-0902-5. (this issue)

Edenhofer O, Knopf B, Leimbach M, Bauer N (2010) ADAM's Modeling Comparison Project - Intentions and Prospects. Energy J 31:7-10. doi:10.5547/ISSN0195-6574-EJ-Vol31-NoSI-1 
Edmonds J, Reilly JM (1985) Global energy: assessing the future. Oxford University Press, New York

Edmonds J, Wise M, Pitcher H, et al. (1997) An Integrated Assessment of Climate Change and the Accelerated Introduction of Advanced Energy Technologies - An Application of MiniCAM 1.0. Mitig Adapt Strateg Glob Chang 1:311-339. doi:10.1023/B:MITI.0000027386.34214.60

Gillingham K, Nordhaus WD, Anthoff D, et al. (2015) Modeling Uncertainty in Climate. A Multi-Model Comparison. Natl Bur Econ Res Work Pap Ser, Paper No. 21637. doi:10.3386/w21637

Jakob M, Luderer G, Steckel J, et al. (2012) Time to act now? Assessing the costs of delaying climate measures and benefits of early action. Clim Change 114:79-99. doi:10.1007/s10584-011-0128-3

Jiang K, Masui T, Morita T, Matsuoka Y (2000) Long-term GHG Emission Scenarios of Asia-Pacific and the World. Technol Forecast Soc Chang 61(2-3):207-229.

Knopf B, Chen Y-HH, De Cian E, et al. (2013) Beyond 2020 -Strategies and costs for transforming the European energy system. Clim Change Econ 4:1340001. doi:10.1142/S2010007813400010

Krey V, Luderer G, Clarke L, Kriegler E (2014) Getting from here to there - energy technology transformation pathways in the EMF27 scenarios. Clim Change 123:369-382. doi: 10.1007/s10584-013-0947-5

Kriegler E, Mouratiadou I, Luderer G, et al. (2013a) Roadmaps towards Sustainable Energy futures and climate protection: A synthesis of results from the RoSE project, Report. Potsdam Institute for Climate Impact Research, Potsdam

Kriegler E, Mouratiadou I, Luderer G, et al. (2013b) Will economic growth and fossil fuel scarcity help or hinder climate stabilization? Overview of the RoSE multi-model study. Clim Change. doi: 10.1007/s10584-0161668-3 (this issue)

Kriegler E, Tavoni M, Aboumahboub T, et al. (2013c) What does the $2{ }^{\circ} \mathrm{C}$ target imply for a global climate agreement in 2020? The LIMITS study on Durban platform scenarios. Clim Change Econ 4:1340008. doi: $10.1142 / \mathrm{S} 2010007813400083$

Kriegler E, Weyant JP, Blanford GJ, et al. (2014) The role of technology for achieving climate policy objectives: overview of the EMF 27 study on global technology and climate policy strategies. Clim Chang 123:353367. doi:10.1007/s10584-013-0953-7

Kriegler E, Riahi K, Bauer N, et al. (2015) Making or breaking climate targets: The AMPERE study on staged accession scenarios for climate policy. Technol Forecast Soc Change 90, Part A:24 44. doi:10.1016/j. techfore.2013.09.021

Leimbach M, Bauer N, Baumstark L, Edenhofer O (2010) Mitigation Costs in a Globalized World: Climate Policy Analysis with REMIND-R. Environ Model Assess 15:155-173. doi:10.1007/ s10666-009-9204-8

Luderer G, Bosetti V, Jakob M, et al. (2012) The economics of decarbonizing the energy system-results and insights from the RECIPE model intercomparison. Clim Change 114:9-37. doi:10.1007/s10584-011-0105-X

Luderer G, Bertram C, Calvin K, et al. (2013a) Implications of weak near-term climate policies on long-term mitigation pathways. Clim Change. doi:10.1007/s10584-013-0899-9 (this issue)

Luderer G, Pietzcker RC, Bertram C, et al. (2013b) Economic mitigation challenges: how further delay closes the door for achieving climate targets. Environ Res Lett 8:34033. doi:10.1088/1748-9326/8/3/034033

Luderer G, Leimbach M, Bauer N, et al. (2015) Description of the REMIND Model (Version 1.6) Available at SSRN: http://ssrn.com/abstract=2697070

McJeon HC, Clarke L, Kyle P, et al. (2011) Technology interactions among low-carbon energy technologies: What can we learn from a large number of scenarios? Energy Econ 33:619-631. doi:10.1016/j.eneco.2010. 10.007

Morita T, Nakicenovic N, Robinson J (2000) Overview of Mitigation Scenarios for Global Climate Stabilization based on New IPCC Emission Scenarios (SRES). Environmental Economics and Policy Studies 3(2):65-88

Mouratiadou I, Luderer G, Bauer N, Kriegler E (2015) Emissions and their drivers: sensitivity to economic growth and fossil fuel availability across world regions. Clim Change. doi:10.1007/s10584-015-1368-4. (this issue)

Nakicenovic N, Alcamo J, Davis G, et al. (2000) Special Report on Emissions Scenarios: A Special Report of Working Group III of the Intergovernmental Panel on Climate. Cambridge University Press, Cambridge, UK, $570 \mathrm{pp}$

Riahi K, Dentener F, Gielen D, et al. (2012) Chapter 17: Energy Pathways for Sustainable Development. In: Global Energy Assessment - Toward a Sustainable Future. Cambridge University Press and the International Institute for Applied Systems Analysis, Cambridge, UK, New York, NY, USA and Laxenburg, Austria, pp. 1203-1306

Riahi K, Kriegler E, Johnson N, et al. (2015) Locked into Copenhagen pledges - Implications of short-term emission targets for the cost and feasibility of long-term climate goals. Technol Forecast Soc Change 90, Part A:8-23. doi:10.1016/j.techfore.2013.09.016.

Riahi K, van Vuuren D, Kriegler E, et al. (2016) The Shared Socioeconomic Pathways: An Overview. Global Environmental Change 
Rogelj J, McCollum DL, Reisinger A, et al. (2013a) Probabilistic cost estimates for climate change mitigation. Nature 493:79-83. doi:10.1038/nature11787

Rogelj J, McCollum DL, O’Neill BC, et al. (2013b) 2020 emissions levels required to limit warming to below $2{ }^{\circ} \mathrm{C}$. Nat Clim Chang 3:405-412. doi:10.1038/nclimate 1758

Schäfer A, Kyle P, Pietzcker R (2014) Exploring the use of dynamic linear panel data models for evaluating energy/economy/environment models — an application for the transportation sector. Clim Change. doi:10. 1007/s10584-014-1293-y. (this issue)

Tavoni M, De Cian E, Luderer G, Steckel J, Waisman H (2012) The value of technology and of its evolution towards a low carbon economy. Clim Change 114(1):39-57

Tavoni M, Kriegler E, Riahi K, et al. (2015) Post-2020 climate agreements in the major economies assessed in the light of global models. Nat Clim Chang 5(2):119-126. doi:10.1038/nclimate2475

UNFCCC (2015) Paris Agreement. United nations treaty collection. Chapter XXVII Environment. TREATIESXXVII.7d.

Van Vuuren D, Riahi K (2011) The relationship between short-term emissions and long-term concentration targets. Clim Change 104:793-801

Webster M, Sokolov A, Reilly J, et al. (2012) Analysis of climate policy targets under uncertainty. Clim Change 112:569-583

Weyant J, Davidson O, Dowlatabadi H, et al. (1996) Integrated assessment of climate change: an overview and comparison of approaches and results. In: Bruce JP, Lee H, Haites EF (eds.) Climate change 1995: Economic and Social Dimensions - Contribution of Working Group III to the Second Assessment Report of the IPCC. Cambridge University Press, Cambridge, United Kingdom and New York, NY, USA, p 371-396 